\title{
The Current Status of University Library Staffs
}

I APPEAR BEFORE YOU this evening with head bloody but unbowed. Perhaps I should be in a chastened mood, since some friends, whose views are considerably at variance with my own on this subject, have expressed grave doubts that I am capable of an objective discussion of the status of university librarians. $^{1}$

The doubts may be well founded, for in previous writings on the matter, my approach, frankly, has been somewhat partisan. Being firmly convinced that the morale, sound development, and allround effectiveness of professional university librarians are related directly to the place assigned them in the institutional hierarchy, I have pleaded for a clear-cut, unambiguous recognition of these librarians as essential members of the academic community.

My assignment for today's program, however, is different. As objectively as possible, on the basis of information provided by 115 leading American universities, I propose to review the present status of university library staffs, professionals only, and then conclude with a summary of current opinion among library administrators as to the most desirable type of personnel organization. The survey is limited to universities, excluding colleges, though the line of demarcation is not always crystal clear, especially with the present trend toward adding the title of "university" to the name of every institution of higher edu-

\footnotetext{
${ }_{1}^{1}$ Paper presented at a meeting of the University Libraries Section of ACRL, June 26, 1957, at Kansas City, Missouri.
}

Dr. Downs is director of the library and library school, University of Illinois. cation, while, on the other hand, a number of institutions which carry all the earmarks of universities are still being called colleges.

A number of librarians with whom I corresponded made the point that we need a definition of academic status. Is it, for example, identical with faculty status? Here is evidently a question of semantics requiring clarification; otherwise, we will often be talking at cross purposes. In many universities, academic status and faculty rank are not considered the same thing. The librarian may feel that he has achieved academic status if he and his staff have been granted certain faculty perquisites, such as attending faculty meetings and marching in academic processions, even though these are not accompanied by academic titles. It is obvious that under this interpretation academic status is something less than full faculty standing.

May I suggest, though I realize this statement is debatable, that university librarians have not established themselves as definitely a part of the academic community until they are recognized as being affiliated with the faculty. In short, academic and faculty should carry the same connotation. Anything less than that leaves the librarians in a kind of limbo, not precisely one thing or another. In practice, then, academic status for the librarian should signify that he meets standards for appointment equivalent to those specified for the classroom teacher. Likewise, in such matters as tenure, salary scales, sick leaves, retirement provisions, and sabbaticals he ought to be on a par with 
other faculty members. As for titles, unless the librarian is actually engaged in formal classroom instruction, it may not be essential for him to be accorded a formal rank, but library positions should be equated with those of the teaching faculty, e.g., an appointment might read "Reference Librarian, with rank of Associate Professor." Such assimilated faculty rank explicitly fixes the librarian's place in the academic scheme and leaves no doubt about his exact status.

Obviously, librarians may enjoy most traditional academic rights and privileges without regular faculty rank, as they are doing in a considerable number of institutions. Nevertheless, they fall short of unqualified faculty status.

So, with this much by way of definition of the terms academic and faculty status, perhaps it will be simpler to make clear the existing situation among university librarians of the country.

An analysis of the replies received from the group of 115 libraries reveals that there are three prevailing patterns for the organization of professional staffs. These are: (1) academic or faculty status; (2) separate professional group, which may be called administrative or professional, or be without any special designation; (3) civil service or other classified service plan. Variations within these three principal categories are numerous. Here is a summary of a rather confused situation.

A total of 35 institutions, nearly onethird of the total, reported that professional librarians are given faculty status, with titles. Another sizable group, about 27 , have been granted academic status without titles. These vary from a few institutions which have developed specific equivalent ranks for their staffs to others which are very nebulous about the definition of academic. These last shade over into an even larger number of universities where librarians are regarded as belonging to a separate pro- fessional group. Some 43 libraries fall into this category. Again, however, the term "separate" or "special professional" can mean almost anything. For example, the librarians may be considered administrative employees, they may be classed as clerical or non-academic, or their status may be so vague and indefinite that no one is quite certain where they belong.

In a considerable number of institutions, it is the practice to grant faculty titles to selected members of the staff and to classify the remainder in some other fashion. About 45 universities follow this plan. Only the chief librarian is granted such recognition in some instances, or it may be extended to associate and assistant librarians and department heads. In still other cases, only librarians who actually teach, either library or non-library subjects, are given titles.

The third principal type of personnel organization, civil service or similar classified scheme of service, is peculiar to state or other publicly supported institutions. Of those reporting, eleven have all or some portion of their staffs so organized. Some libraries make exceptions for, or exempt from classified service, the top-ranking members of their staffs. At Minnesota, for example, all library department heads were transferred a year ago to full faculty status, while the remainder of the staff is under university civil service. Similarly, at Wisconsin, faculty rank is given to the director, his associates, heads of departments, and assistant heads of departments, with all others on state civil service. At Maryland, about one-third of the professional members have faculty status and the others are under a state classified system. These cases are typical of others in the group which includes all branches of the University of California, University of Texas, University of Massachusetts, Howard University, Utah State Univer- 
sity, University of Virginia, and Virginia Polytechnic Institute.

Practical indications of the standing of librarians in an institution are provided by the kind of treatment they receive in such matters as salary scales, tenure, sabbaticals, sick leaves, retirement provisions, and academic vacations. Following is a review of the prevailing situation with respect to these several aspects of the librarian's working conditions:

Salary Scales. In only a handful of institutions is any attempt made to establish identical or comparable salary scales for librarians and teaching faculty. Often, apparently by chance, salary levels, especially for lower ranks, are approximately the same. Where there are differentials, library salaries are not necessarily inferior. In some instances, they may average somewhat higher at the instructor-assistant professor level. The acute shortage of librarians which has prevailed throughout the country in recent years has done much to correct poor library salary conditions. One university librarian stated that he would be unwilling to assign faculty titles to his staff if this meant that their salaries would be equated with those of instructors and assistant professors in such fields as English and French, though he would not be averse to having them paid on the engineering faculty scale.

A closely related phase is the question of financial recognition of the fact that librarians are usually on twelve-month rather than academic-year appointments. In some institutions, an exact percentage is added to a base salary for year-round service-which actually means in most cases eleven months out of the year. The percentage varies considerably, however, with, for example, Rutgers and Oklahoma A. \& M. College allowing a 10 per cent bonus; South Dakota State College and West Virginia University 15 per cent; University of Arkansas 20 per cent;
University of Denver 25 per cent; University of Georgia 30 per cent; and University of Illinois two-ninths. In a majority of cases, though, there was either no recognition of the longer work period required of librarians, or adjustments were made on an individual basis without the use of any fixed formula. From my correspondence, it was apparent that librarians and university administrators were conscious of this problem and in a number of institutions were working toward finding a proper solution.

There was no indication here, necessarily, that librarians were being discriminated against. In frequent instances, all or a substantial portion of a university's staff were on annual appointments. Especially in state institutions, research and extension staff members in agriculture, engineering, and home economics serve eleven months out of the year, with a month's vacation. And, of course, this is nearly a universal custom with respect to administrative officers, presidents, deans, directors, and sometimes department heads.

Vacations. The same principle carries over into vacation allowances. It is the exception rather than the rule for librarians to receive more than the standard one-month vacation, to which may be added the usual holidays scattered through the year. Because library service is a continuous operation, it is generally agreed that, at least in this respect, librarians should be treated like members of the administrative staff, rather than receiving the long academic vacations typically a perquisite of the classroom teacher. This rule is unlikely to change, unless ways and means can be found to increase substantially the size of library staffs. One institution, Utah State University, which has ninemonth contracts for its librarians, reported that the short contract created real problems, "the chief one being the 
allocation of duties to adjust to the absence of a professional for three months."

Sick Leaves. In the matter of leaves required by illness, universities are almost invariably generous. The usual practice is to treat the faculty and professional librarians alike in granting such leaves. In some institutions, cases are decided on an individual basis. In others, there is a standard allowance of a given number of days, weeks, or months off with full pay for each year of service.

RETIREMENTs. In a majority of cases, faculty members and librarians are under the same retirement system, receiving identical rights and privileges. In a few institutions, e.g., California, Chicago, Colorado, Harvard, Pennsylvania, Rochester, and Virginia, separate retirement plans are in effect for all or a majority of the library staff. These may or may not be inferior to those provided for the teaching faculty. In several instances, it was claimed that provisions of the plans covering librarians were more liberal than those for the faculty.

Sabbaticals. Sabbatical leaves for librarians are relatively rare. Only 22 out of the 115 universities questioned granted such leaves regularly or occasionally. Others were reasonably generous in giving leaves with pay for advanced study, particularly when such study was judged to be of direct benefit to the institution. A surprising number of universities, by the way, make no provision for sabbaticals for their teaching faculties or for any other members of their staffs. This is a fringe benefit that might well concern such organizations as the AAUP and the American Federation of Teachers.

Tenure. Tenure as applied to librarians is in a somewhat anomalous state. Actually it is not a problem, since the shortage of librarians prevailing since 1940 has made libraries happy to retain staff members with any merit whatever. Under the traditional rules for academic tenure, however, only faculty members with the rank of professor or associate professor are entitled to permanent or indefinite tenure. In a few instances, it was reported that special rules had been devised to cover libraries. For example, the University of Rochester gives indefinite tenure to professional librarians after one year of satisfactory service, while Louisiana State University makes appointments permanent after three years. Under California's classified system, Donald Coney pointed out, "Tenure is not stated as such, but grievance procedures and hearings give virtual tenure and make dismissal without just grounds impossible." This is an advantage or disadvantage, depending upon the point of view, of civil service regulations. Several librarians commented that, in regard to tenure, librarians were in a more favorable position than the teaching faculty. In the faculty, those with the rank of instructor or even assistant professor are on temporary appointment, and are expected to move on after a stated period of time. Such rules do not govern librarians, who therefore have more permanence and more security than classroom teachers.

Other Perquisites. Occasionally mentioned were other perquisites, coming to the library staff, of a nature similar to those accorded the faculty. Several indicated that group insurance and group hospitalization plans were made available to librarians on the same basis as to the faculty. Tuition exemption for the librarians and, in a few cases, for their children, a faculty privilege, was extended to the librarians at Columbia, Georgetown, Notre Dame, etc. Also frequently listed were such minor forms of recognition as membership in faculty clubs, attendance at faculty meetings, membership on faculty committees, and marching in academic processions. While 
not of major significance, these were considered indicative of acceptance by the faculty of professional librarians on a somewhat equal footing.

\section{In SEARch of an Ideal}

As the concluding question in the inquiry sent to the university librarians of the country. I asked for personal opinions as to the most logical and satisfactory status for professional librarians in a university. Since the sentiments expressed represent the university library leadership of the country, the results are significant. After all, if any progress is to be made toward an acceptable resolution of our difficulties in this field, these are the men and women who must cooperate in and direct any improvements. Exactly how the judgments of their librarians ought to be interpreted, however, poses a dilemma, for the problem is still controversial, and wide disparities in viewpoints exist.

A preponderance of opinion favored "academic" status for librarians, but the definition of academic and the question of which members of the staff should be covered by the term were almost as varied as the respondents. Reading from left to right, i.e., from those who advocated faculty rank for every member of the professional staff to those who were disposed to resist to the limit the inclusion of librarians in the academic category, let me attempt to summarize the prevailing thought, making free use of direct quotation.

Stuart Baillie, University of Denver: "Any method of classification other than faculty status for librarians abandons the possibilities and values of cooperation with a larger and more powerful group, namely the faculty. All other methods which I have observed result in poorer salaries and less than comparable working conditions."

Flint Purdy, Wayne State University: "I am very much in favor of complete equality for librarians. I see no justification for their traditional status as second rate citizens."

John Ottemiller, Yale University: "Professional librarians in a university should have academic status which includes all of the rights and privileges of the faculty and comparable salary scales."

Lewis Branscomb, Ohio State University: "The only status for librarians which I feel to be fully satisfactory is that of faculty rank and title for each member of the professional staff, designed to provide the best possible atmosphere in which librarians can really perform as academic members of the university community."

Kenneth LaBudde, University of Kansas City: "In the future a director can not build a library staff which will perform in a satisfactorily academic manner unless its members have full academic status. A director knows he can make the library the heart of the university only if he has highly qualified personnel. He can not attract such people if the institution does not recognize their worth by the status which it accords them."

Norman Kilpatrick, Florida State University: "It is extremely helpful in hiring staff to be able to give them academic rank. ... As I reflect upon the present modern university set-up with its various administrative officers, counselors, and others who take an active part in student education, it seems to me that there is less and less reason for a university to make hard and fast distinctions between the faculty that teach in the classrooms and those who teach outside the classroom."

Ralph Parker, University of Missouri: "My opinion on the most satisfactory status for librarians has changed within the past ten years. In both institutions where I was chief librarian before coming to the University of Missouri, mem- 
bers of the library staff had full faculty status. At that time I considered status unimportant. At the University of Missouri I see that there are many difficulties which are reflected in the institutional policy of not granting faculty status. I have come to feel that faculty status for librarians is not of itself significant, except that institutional attitudes which are conducive to better library service will also favor the granting of faculty status as explicit evidence of that attitude."

Howard Rovelstad, University of Maryland: "After considerable study of the question of faculty status, I am completely convinced of the desirability of being identified with the faculty. The only means of obtaining this identity for the entire professional staff is to be granted faculty status."

Thelma Brackett, University of New Hampshire: "Since faculty status was achieved for all librarians, there has been a marked improvement in faculty relationships and in librarians' morale. I am firmly in favor of the present arrangement and see no logical argument against faculty status for all professionally trained librarians."

Archie McNeal, University of Miami: "I feel that close identification with the teaching staff is likely to produce a better understanding of the role of the library in the educational program, and encourages the faculty to share with the library staff in developing the resources needed to accomplish their purpose."

William Jesse, University of Tennessee: "Of all the arguments for faculty rank, I believe the one of giving the individual a sense of belongingness with the academic rather than the non-academic or nebulous groups is the most valid. We have had academic rank for seven years, and it has been most helpful."

William Baehr, Kansas State College: "There has to our knowledge never been any question about the wisdom and the propriety of according faculty rank to librarians on this campus. We make it a point in our contacts with the faculty to emphasize the advanced type of training that we require on the part of professional librarians. ... I constantly hear from both library workers and from members of the teaching faculty that one of the greatest values in faculty standing for the library staff is in the area of recognition and acceptance on the part of the rest of the faculty. It improves the morale of the library staff and it adds to the confidence of the general faculty in the library staff. I find the matter of faculty standing important when trying to persuade library school candidates to come to Kansas State."

The foregoing comments are representative of those received from about forty librarians who were on the side of unqualified faculty status. Another considerable group adopted a middle-ofthe-road attitude, suggesting a gradual approach, or faculty status for selected members of the staff. This group tended to emphasize qualifications for appointments. Typical were the views stated by Daniel J. Reed, University of Detroit:

"I believe that the majority, if not all, librarians should have faculty status, but they must be fully worthy of it. They must be in some sense scholars and teachers comparable to the rest of the teaching faculty. Merely technical competence is not sufficient grounds for granting faculty status to professional librarians. ... I am much more interested in a librarian's general education and in his competence in some field of knowledge that I am in his grasp of techniques. University librarians must know something about the inside of books. I have no reservation about giving faculty status to this type of librarian."

A similar point of view was expressed by Edmon Low of Oklahoma A. \& M. 
College: "I feel the usual library school Masters graduate without experience, who is immediately given the rank of instructor, is not as extensively or as rigorously trained, and perhaps not as able, as is the average instructor in the subject fields for which a Ph.D. is usually required. More favorable comparisons can be made, however, in engineering, home economics, and other fields of the pure and applied sciences where many practical compromises are made."

Other aspects were stressed by Donald Smith, Washington State College: "The privileges of faculty appointment are very nice indeed-tenure, salary, sabbaticals, and the rest. But faculty membership carries with it faculty responsibility as well: membership on faculty committees throughout the institution, participation and leadership in the intellectual life of the institution and the community, etc. It requires professionalism in the real sense of the word rather than the watered-down version commonly used. . . . Faculty membership based on the possession of a library school degree seems to me of very doubtful value. I would prefer to have the library staff attached to the academic administration, but not automatically members of the faculty, and with provisions for giving individuals real faculty status when they have demonstrated their intellectual qualifications and have been accepted as colleagues by the instructional and research groups."

Mr. Smith's attitude was supported by L. H. Kirkpatrick of the University of Utah: "I believe for university staff members to receive the status they want they must be careful to conduct themselves as members of a profession. This includes a keen interest in the intellectual life of the campus, fidelity to the welfare of the institution beyond punching a clock, and using their talents in professional work rather than spending part of their time in work which clerical help could do." Mr. Kirkpatrick conceded, however, that, "It is hard to separate, even in teaching, all of the sub-professional work from the professional group. Many teachers regard correcting of tests and papers as something which is purely clerical while others claim it is a very important part of the teaching process. The same thing goes for certain areas in library work."

Several penetrating observations were also made by Eugene Willging of Catholic University: "In general I would think that it would be a mistake to state that all professional librarians in colleges and universities should be granted ex-officio academic status on the same levels as faculty members. . . . Wherever professional library knowledge is added to academic subject knowledge, as in the case of departmental and divisional libraries, and wherever the individuals involved through their own experience seem to deserve such status then I believe a case could be made. Therefore, it is my opinion that you can't adopt a straight across-the-line policy in this respect. Each case probably should be judged on its own merits and should be passed upon by a joint academic-library committee much along the same line that promotions are handled from the academic side."

Robert Vosper, University of Kansas, might be described as a reluctant convert to the idea of academic status. "My personal conviction, which may be somewhat old-fashioned," stated Mr. Vosper, "is that professional librarians should and can maintain a position of dignity and importance on the campus simply as librarians and without necessarily tying themselves onto a faculty pattern. I think they should and could secure as many specific 'privileges' as they may want, but I think these can be secured in most cases without adopting formalized faculty titles and the like. I have a conviction that without too much overt 
effort librarians, simply as librarians, can achieve whatever status they want if they will only produce adequately in the academic community. By this I mean that any librarian who displays genuinely academic competence, such as by publishing, will be accepted at face value in the academic community and will receive all the privileges he may wish. On the other hand, I have a frank feeling that too many librarians want something called academic status without really being willing to face up to the responsibilities involved to the same degree that the teaching staff measure up. This involves continual growth and education on one's own, publication or something equivalent, wholehearted participation in the total academic program, and the like. All that I have said so far reflects a very personal opinion and one that is shared by a small number of my colleagues, but on the other hand I recognize that the majority of this staff, as well as many another staff, wants some kind of formalized academic status and that good morale probably requires it these days. Moreover, the trend seems slowly to be in this direction, so my general policy has been to accept the fact that I am in a minority opinion. Consequently, I am taking steps to try to secure some kind of formalized situation here."

Mr. Vosper is by no means alone in his view that, as Paul Buck of Harvard expressed it, "Librarians in a university should stand on their own feet as contributors of an essential element in the total educational function of the university." Mr. Buck went on to say that, "Librarians should be recognized as skilled professional workers who must meet high standards to qualify for successful work in a complex research library. Such recognition should be reflected in salary scales commensurate with their qualifications and the important tasks they perform. Their status should be fully as professional as that of the teaching staff, with participation in the faculty retirement plan, medical insurance, faculty club, and other social organizations and with all other privileges that will contribute to their fullest professional effectiveness. Librarians in policy-forming positions should of course be voting members of the faculties."

Mr. Buck's point of view was endorsed by Guy Lyle of Emory, Eugene Wilson of Colorado, Benjamin Powell of Duke, John Berthel of Johns Hopkins, and others.

On the other hand, we have the voice of experience speaking in the person of Ralph Ellsworth, who remarked, "In a way, I agree with those who feel that the term 'librarian' best describes us, that we should not seek other titles but rather should insist that librarians have the same privileges and working conditions the teachers do. The trouble with this is that things don't quite work out that way. The Illinois solution i.e., academic status for all professional librarians $_{\text {] }}$ is best in the long run, in my opinion, because if given a chance to operate 25 years, it will create the best kind of service to students and faculty, and that is what we should be thinking about!"

The "separate but equal" concept, which, incidentally, the U. S. Supreme Court rejected in another connection, is in vogue in a number of libraries. J. R. Ashton of the University of North Dakota, for example, advocated a special classification for professional librarians, which, he suggested, "would ideally have five steps, corresponding to academic rank from instructor to dean, would carry salary equal to twelve-ninths of the salary of the corresponding academic rank, and would entitle the librarians to all privileges and responsibilities of the faculty."

Likewise, Hugh Montgomery of the University of Massachusetts believed 
that "professional librarians should have the same status as academic faculty but should not be tied in directly with teaching positions insofar as classification is concerned." He favored "the idea of an administrative classification which is comparable with the academic classification."

An equivalent classification schedule was also recommended by Lewis Stieg, University of Southern California, William Ready, Marquette University, Marvin Miller, University of Arkansas, William Dix, Princeton University, and others.

An interesting compromise solution was proposed by Raynard Swank, Stanford University. Mr. Swank suggested that a university's entire staff be divided between academic and non-academic. The academic staff would be further divided into two main groups: first, the teaching faculty, and second, other professional members, including librarians, research associates, counselors, etc. "This conception," suggested Mr. Swank, "calls for academic status for librarians along with other professional non-teaching groups in the University, but it avoids the difficulties, compromises, and sometimes embarrassments attendant upon the effort to fit librarians into categories designed for the teaching faculty. I would rather see librarians recognized as academic, as equals to the faculty, in their own right as librarians than dependent for their status upon the imitation of faculty ranks."

Still another form of organization is possible: a classified or civil service type of personnel set-up. In general, university librarians view civil service with a jaundiced eye. There are defenders, however, who maintain that it has some sound features. Louis Kaplan, University of Wisconsin, for example, stated that, "State civil service gives us many advantages. It gives us ready-made a good set of rules with respect to hours of employment, sick leave, etc. For our top positions, where the formal rules of state civil service are a handicap, we are fortunately free to give faculty status, but this too has its disadvantages in that salary promotions are less regular compared to those given to the classified civil servants."

The most conspicuous illustration of a classified service for professional personnel is the system which prevails throughout the University of California Libraries, Berkeley, Los Angeles, and elsewhere. There the library staff is part of the non-academic staff of the University, and are subject to the University's non-academic personnel policy as administered by the Personnel Office. Library classifications and pay scales, both professional and non-professional, are established by the President. Development of classification and pay scales is carried on by the non-academic Personnel Office in consultation with the Library administrators. Donald Coney at Berkeley and Lawrence Powell at Los Angeles are confident that the plan provides a logical and satisfactory status for the University's professional librarians. Mr. Powell noted that the professional library staff at California participated in and agreed with the decision to include librarians in the category of non-academic personnel.

There may not be complete unanimity on the virtues of this system, however, for the director of a university library in another region of the country, formerly associated with California, advised against permitting professional librarians to fall under the California type of non-academic personnel administration.

A new element was injected into the picture of status last year when the Council of the American Association of University Professors ruled "that librarians of professional status are engaged in teaching and research," and therefore 
are eligible for AAUP membership. What is meant by professional status? As interpreted by the AAUP Council, an applicant for membership must meet three conditions: (1) Have an appointment at an eligible institution for at least one academic year; (2) have "the status of member of the faculty, or the academic rank of instructor or its equivalent or higher, at that institution; and (3) his work under that appointment consists of at least half-time teaching or research or both." Obviously, these conditions could be met only by librarians who have been granted academic status. Otherwise, they are ineligible for membership in this large, influential organization, sometimes facetiously referred to as the "Professors' Union." According to a recent report, 738 librarians have joined the AAUP, making librarians twentieth in a list of 46 subject fields.

Are there any valid conclusions that can be drawn from the wide range of viewpoints represented by the librarians from whom I have quoted or whose opinions I have summarized? Actually, I believe that we are much closer to a consensus than may appear on the surface. Though university librarians may differ on the best methods to achieve the desired goals, there appears to be complete unanimity among them on these points:

1. The maintenance of high standards for professional staff appointments, in order to place the preparation of librarians as nearly as possible on a par with their colleagues in classrooms, and to insure top-notch library service to faculty and students.

2. Through academic status, equivalent rank, or special professional classification to entitle librarians to all appropriate rights, privileges, and perquisites received by the teaching faculty.

3. To obtain general acceptance and recognition of the essential value of the librarians' contribution to the educational and research programs of the universities of the country.

These matters are basic. Much less certainty prevails as to what kind of organizational machinery will best serve to reach the broad objectives. An overwhelming majority of university library administrators, however, have apparently come to the conclusion that close identification with the teaching faculty is most likely to accomplish our aims. This may take the form of (1) faculty status, with each librarian assigned suitable rank in the faculty hierarchy, or (2) inclusion of the professional staff in the academic classification, with equivalent ranks, or (3) definition of librarians as academic without any attempt to integrate exactly library positions with faculty ranks.

A minority of the respondents favored other solutions. Most of these supported the position that librarians should be self-reliant and independent, rather than being incorporated into the teaching faculty. Even some librarians who voted for academic status expressed the wish that librarianship might eventually win recognition as deserved, distinct, and well defined as longer-established professions. In that case, as one person expressed it, "they should take pride in their own separate status as librarians." Doubtless, from a long-range point of view, we are all convinced that we should work toward strengthening librarianship as a profession. Viewing the matter realistically, however, we know that cannot be accomplished overnight, and meanwhile, as a well-known statesman once remarked, "It is a condition which confronts us, not a theory." It should also be pointed out that the lawyers, doctors, dentists, engineers, chemists, architects, ministers, and other members of solidly established professions are ordinarily given academic titles when employed on a university faculty or staff. If librarians contribute as sub- 
stantially as we believe that they do toward the achievement of an institution's educational purposes, why should they not also be accorded formal recognition?

A fitting conclusion to this discussion might be a quotation from a letter written by Roscoe Rouse, Baylor University, who commented, "This, like many university library problems, has no set answer. I think it is a mistake for anyone or any association to proclaim that all college and university librarians in the country should have faculty status. Each campus has its own distinct problems." Incidentally, the entire professional library staff at Baylor has faculty status.

As Mr. Rouse pointed out, conditions vary from one institution to another. In some of the older, privately endowed universities, for example, the requirements for professorial appointments are extremely rigid. The teaching faculty is jealous of its prestige and is opposed to bringing into its ranks any who do not conform to the traditional patterns for academic training and advancement. For like reasons, I might add parenthetically, these individuals often fight the introduction of new disciplines, seeking to preserve the classical nature of the university's curriculum. In such situations, the librarians may have to settle for an administrative classification, or perhaps for a ruling identifying them as belonging to the academic category without faculty status. Other institu- tions, more typically state universities, are flexible in their definition of faculty, and may include the research staff, extension workers, librarians, editors, deans, athletic coaches, student counselors, radio and television personnel, and others who play a direct and substantial part in the educational and research activities of the institution.

At the beginning of this report, I promised to make my presentation of this subject as unbiased as possible. To conclude my remarks, however, I want to throw in a small amount of bias, or at any rate some personal opinions. First, as librarians, I do not believe that we want to cheapen high standards for faculty appointments by according such standing to poorly-qualified staff members. Librarians must offer equivalent qualifications if they are to expect academic recognition. In some instances, if an entire staff cannot come up to the specifications, a gradual approach may be preferable. Furthermore, for academic advancement, criteria similar to those used for the teaching staff should be followed, including, in addition to educational and professional attainments, continued interest and participation in the activities of library associations, research in problems of librarianship, writing for publication, and other evidences of professional maturity. Given these basic conditions, I have not the slightest doubt that librarians should be accepted as an integral part of a university faculty.

\section{Mayo Celebrates Jubilee}

The Mayo Clinic Medical Library is celebrating its jubilee year. The library was established as a unit March 1, 1907. The collection now totals ninety-five thousand volumes. It is particularly strong in basic journal literature of medicine and in rare editions of the early medical treatises.

The clinic staff have William W. Mayo to thank for his early recognition of the value of a good library to effective medical practice and research, for the personal collection of Dr. Mayo provided the nucleus for the library. 